Promemoria Bounaparcie, czyli ambiwalencje bonapartyzmu w polskiej anonimowej broszurze z końca XVIII wieku

Marian Skrzypek 


\section{Marian Skrzypek}

\section{Promemoria Bounaparcie, czyli ambiwalencje bonapartyzmu w polskiej anonimowej broszurze z końca XVIII wieku}

7 arówno kult, jak i czarna legenda Napoleona, które rozwijały się w Polsce równolegle, przybierały juz w swoich początkach nader zróżnicowane formy, a podstawowe ich wątki przeplatały się ze sobą. Wynikalo to ze złożonych warunków społeczno-politycznych oraz ich ewolucji związanej ze specyficznym przyspieszeniem historii między klęską maciejowicką i klęską armii napoleońskiej pod Waterloo. Zlota i czarna legenda Napoleona splataly się ze sobą również na tej zasadzie, jak jego tryumfy i klęski, odkąd (w 1794 roku) stal się generalem, a następnie (w 1804 roku) cesarzem i człowiekiem decydującym o losach Europy. Dla Polaków szczególnie znaczące były daty mieszczące się w dwudziestoleciu 1794-1814, a mianowicie utworzenie w 1797 roku polskich legionów, ustanowienie w 1807 roku Księstwa Warszawskiego, odwrót spod Moskwy (1812) i klęska pod Lipskiem (1813).

Już w okresie formowania się legionów picrwszym oponentem wobec Napoleona był Kościuszko, który sądził, że droga do niepodległości kraju wiedzie poprzez ogólnonarodowe powstania Polaków, a nie poprzcz interwencję z zewnątrz. Jego niechętny stosunek do generala Bonapartego wzrastał, w miarę jak ten coraz wyraźniej odchodził od republikańskich tradycji Rewolucji Francuskiej i przejawiał zapędy dyktatorskie. Szukanie jednak zalążków polskiego antybonapartyzmu w kręgu ludzi związanych bezpośrednio z Kościuszką byłoby uproszczeniem, gdyż powstawały one w różnych, często niezwiązanych ze sobą środowiskach. Wskażemy więc na niektóre z nich.

Głosy krytyczne wobec Napoleona pojawiają się już w początkach jego kariery nawet wśród jego entuzjastów, upatrujacych w nim potencjalnego wyzwoliciela Polski. 
Wśród nich wyróżnili się studenci Krakowa'. Oto przepojony antykolonialnymi tyradami Raynala-Diderota, których skopiowane ręcznie fragmenty pozostawił, młody poeta Józef Sygiert, uczeń Jacka Idziego Przybylskiego, określa walkę Napoleona z powstańcami na San Domingo jako haniebną. W ich murzyńskim generale Toussaint Louverture widzi „czarnego Spartakusa”, kładąc tym samym nacisk nie tylko na narodowo-wyzwoleńczy, ale również plebejski charakter powstania. W liście pisanym z Wiednia do rodziców w dniı 19 lutego 1803 r. donosi:

Tymczasem Francuzi już zupełnie wynieśli się z San Domingo; jakieś widzę przeznaczenie Bonapartego, że tylko przeciw hołocie jego plany się nie udają.

Fakt ten zdaje mu się zwiastować narodziny ruchu antykolonialnego o szerszym zasięgu, gdyz dodaje:

Jeżeli duch Tussenta Luwertura będzie Negrów ożywiał, doczekamy się ciekawego zjawiska na politycznym niebie.

Walka legionistów przeciwko powstaniu tubylców San Domingo prowadzona w imię hasła „Ludzie wolni są braćmi” jest według Sygierta największym paradoksem i największym dramatem Polaków, którzy zaczęli wątpić, czy walczą za wolność swoją i cudzą. Dlatego nie ukrywa satysfakcji, donosząc w liście, że „dwa bataliony legionistów polskich przeszly na stronę Murzynów" ${ }^{2}$. Podobne myśli krążyły wśród samych legionistów. General Antoni Kosiński sądzil, że legioniści wysłani na San Domingo byli „niewolnikami przymusu” i musieli „strzec więzień, w których wyrodna chciwość Europejczyków dręczy nieszczęśliwych Murzynów”’. Pułkownik Józef Paszkowski wspomina po latach, iż

trudy legionistów osładzała myśl, że to było dla Polski, a oni byli jej reprezentantami. Mieszkańcy San Domingo nie przyczynili się do jej rozszarpania. Nie pozostawało, tylko chwałę oręża utrzymać, i tę nawet sobie Francuzi przywłaszczyli, nigdzie wyraźnie nie wspominając o waleczności Polakówł.

Również Aleksander Fredro pisze w swoich wspomnieniach z kampanii napoleońskiej, że „Polacy ubóstwiali Napoleona”, ale na wieść o utworzeniu Księstwa Warszawskiego zadali sobie pytanie:

\footnotetext{
'Por. J. Snopek, Prowinga ośu'iccona. Kultura literacka Zicmi Krakowskicj u' dobie Ośuriecenia, 1750-1815, Warszawa 1992, s. 306-313.

2Por. M. Skrzypek, Filozofia Diderota, Warszawa 1996, s. 252.

3 J. Pachoński, Legiony polskie. Prau'da i legenda. 1794-1807, t. 4, Warszawa 1979, s. 415-417.

+ Ibidem, s. +13 .
} 
Czy znowu w St. Domingo szukać będziemy Ojczyzny naszej? Zawsze opuszczeni przez Francuzów, zawsze jednak ciśniemy się do nich. Księstwo nasze samo przez się istnieć przestanic, jeżeli jego wojsko pod obcym królem, za obcą sprawą wyginie do szczętu".

Podobne rozterki legionistów sygnalizuje w 1805 roku w Grenadierze-filozofie i w Wierszu do legión polskich Cyprian Godebski. Przeżywał on dotkliwie fakt, że Polacy odczuwali wyraźnie, iż walczą „o cudzą sprawę”, pocieszając siç jednak, że „to dla ojczyzny".

O dramacie Legii Naddunajskiej walczącej na San Domingo Godebski pisał:

Szliście na głos braterstwa, lecz - o losie srogi!

Ten grób znalazł, ten wróci bez ręki lub nogi,

Oddalony od braci, domu i rodziny,

Niejeden pije gorycz w pośród słodkicj trzciny,

A drugi, przebiegając okropne pustynie,

Lub cudzy głód nasyca, albo własnym ginie.

O hańbo! O ślepoto w ludziach niepojęta!

Ten, który został wolnym, poniósł drugim pęta!

Poniósł, ale słusznego nie uszedł pogromu!

Znalazł lub zgon za morzem, lub niewolę w domu.?

Utworzenie Księstwa Warszawskiego wywołało powszechny entuzjazm dla Napoleona, ale też nadzieję na pełną suwerenność, a więc wrażenie niedosytu. Nawet tak wytrawny polityk jak I Iugo Kollątaj widział w tym „niemowlęciu politycznym" zalążek przyszlego państwa buforowego między napoleońskim Imperium Zachodnim a Imperium Wschodnim Aleksandra I. Snuł więc wizję odbudowania Polski w granicach z okresu jej największej świetności, która rozciągałaby się od Baltyku po szczyty Krępaku i po brzegi Morza Czarnego, od Odry do Dźwiny i Dniepru. Kołłątaj aprobuje bez wahania nowy ustrój społeczny Księstwa Warszawskiego oparty na Kodeksie Napoleona, który wprowadził wolność osobistą chłopów i równość wszystkich obywateli wobec prawa. Jako zwolennik „łagodnej rewolucji" Kołłątaj nie dostrzegał w Napoleonie dyktatora, który sprzeniewierzył się ideom Rewolucji Francuskiej, sądził natomiast, że położył on jedynie kres władzy „anarchistów”.

${ }^{5}$ A. Fredro, Trzy po trzy', Warszawa 1996, s. 21.

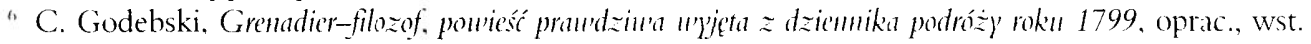
i koment. Z. Kubikowski, Wrocław 1953, s. 16.

${ }^{7}$ Idem, Wicrs do legión polskich, w: C. Godebski, Wytor wierszy, oprac. Z. Kubikowski, Wroctaw 1956, s. 31 . 
Gdyby nie ta rewolucja - powiada - lud francuski nie przetworzyłby się na lud zupetnie nowy, nie usposobilby się do tych dzieł wielkich, do jakich go Napoleon doprowadzil, a które sprawiedliwie nazywać się mogą dzielami Herkulesa. Tak więc niespodziewana w tych wypadkach i osobliwie w swych skutkach rewolucja może być uważana za prawdziwe Opatrzności dzieło, bolesne na pozór i tyle przynoszące pożytku dla całej społeczności ludzkiej; było to zło konieczne, z którego tak wielkie dobro wyniknąć miało".

Kołlątaj gotów był aprobować Księstwo Warszawskie jako ważny krok podjęty przez Napoleona w kierunku pełnego wyzwolenia Polski w przyszłości. W ostatnim swoim niedokończonym dziele, będącym francuskim wariantem Porządku fizyczno-moralnego, wyraża jednak zaniepokojenie przygotowaniami do wojny Napoleona z Rosją. Obawia się, że wobec niepewnych losów tej wojny Polacy mogą stracić to, co udało im się już zyskać, dysponując własnym państwem. Apeluje więc do Napoleona i Aleksandra I o pokojowe rozwiązanie politycznych napięć. Sądzi, że reprezentujący starą Europę car rosyjski winien zaakceptować Prawdę rozumianą jako całokształt reformatorskiej myśli oświeceniowej, której uwieńczeniem byłoby respektowanie praw człowieka.

Wladcy narodów — pisze Kolłątaj — wy, którzy trzymacie w ręku stery państw, rozważcie, czy nie ma innego sposobu poza samą Prawdą na uciszenie tej burzy, która stała się tak niebezpieczna dla was i dla waszych ludów. Zastanówcie się tylko, czy dla ratowania waszych własnych interesów należy polegać na sile armii, czy też na bogactwach skarbów pochłanianych przez wojnę podjętą przeciwko waszym wlasnym interesom. Doświadczenie nas uczy, że największe mocarstwa ziemi upadły pod ciężarem rewolucji spowodowanych przez poglądy niegdyś tak doniosłe. Jedyny środek, który wam pozostaje, to pogodzenie się z Prawdą i zmodyfikowanie samych siebie zgodnie z jej świętym głosem, który nie może naruszyć interesów, jak również interesów waszego ludu. Jedynie Prawda może ustrzec wasz lud od zuclıwalstwa nowatorów, to ona umacnia wasz tron i prawa; to ona położy kres wszelkim klęskom publicznym, które dręczą ludzkość przytłoczoną bezmiarem nieszczęść; tylko ona wyrwie niszczycielski miecz z rąk obydwu partii i przywróci ziemi spokój, ład i powszechne szczęście".

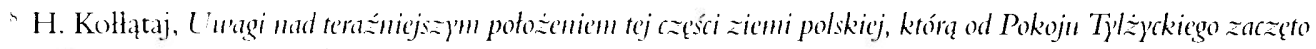
zu'ać Kisçstu'tm Warsant'skim. Nil Desperandum!, Lipsk 1810, s. 108.

" II. Kothątaj, Prau'a i obouriązki naturalne czfou'icka oraz o konstytucji u' ogólności, oprac. M. Skrzypek, Warszawa 2006 , s. 7. 
Kołlątaj nie doczekal wydarzeń, przed którymi przestrzegal Napoleona i Polaków. Zmarł w przedostatıi dzień lutego [tzn. 28 II — rok był przestępny] 1812 roku, zaś wojska Napoleona, rozpoczynając wojnę z Rosją, przekroczyly Niemen 24 czerwca. 15 października zaczął się odwrót ze spalonej Moskwy. 28 listopada miała miejsce tragiczna przeprawa przez Berezynę. Niespełna rok później w trzydniowej bitwie narodów pod Lipskiem (16-19 X 1813) kończy się okres wielkich zwycięstw napoleońskich. Właściwy finał następuje 31 marca 1814 roku, kiedy wojska rosyjskic i pruskie wkraczają do Paryża, a 2 kwietnia senat oglasza upadek Cesarstwa i początek Restauracji. 6 kwietnia Napoleon abdykuje, a dwa dni później jego posąg zostaje strącony z kolumny Vendôme. Upadkowi rzeczywistemu potrzebny był „upadek" symbolu.

Tym sposobem ziszcza się przestroga Kollątaja. Następuje okres rozczarowań i pełny rozkwit czarnej legendy Napoleona w Europie. Ówczesny stan ducha Polaków bezpośrednio po klęsce pod Lipskiem oddają rozmowy polskich uczestników bitwy, które przekaże nam Aleksander Fredro:

Z upadkiem Francji upadły i nadzieje Polaków. Ale mniemaliśmy, że dopiero pod Lipskiem tracimy powtómie Ojczyznę, nie wiedzieliśmy, że Napoleon najłatwiej zawsze przyjmowal warunek wrócenia jej w potrójne jarzmo niewoli. Piekielna obłudo! Tyle poświęcenia, tyle krwi przyjmować za nadzieje, których w głębi scrca nie myśli się spełnić. Skrępował nas tym Księstwem Warszawskim, tym królem saskim, i kiedy pozbawił wszelkiej samodzielności, jak martwą swoją własność był zawsze gotów rozrządzić. Biada człowiekowi, którego los zawisł od drugiego, ale dwakroć biada narodowi, co zawisł od interesu innego narodu! Narody sumienia nie mają".

Trudno byłoby znaleźć trafiniejszy przykład dla zilustrowania przełomu, który nastąpil po bitwie pod Lipskiem i nie byl jedynie przełomem militarnym, bo objąl sferę patriotycznej świadomości Polaków. Przewartościowaniu ulega zwłaszcza idea braterstwa narodów przejmowana przez polskich legionistów w spadku po ideologach demokratycznych stronnictw Rewolucji Francuskiej. Głosili ją w Kole Społecznym Claude Fauchet i Nicolas Bonneville (1790-1792), a następnie radykalni jakobini, wśród których rozmachem swych poglądów oraz ich radykalizmem wyróżnil się JeanBaptiste Cloots, autor dzieł: L'Orateur du genre humain (1791), La République universelle (1792) i Basses constitutionnelles de la République du genre humain (1793)". Występując jako

\footnotetext{
'" A. Fredro, Trzy' po trzy, op. cit., s. 21.

"Obszerniej na ten temat w: M. Skrzypek. Kult redzaju ludzkiego. Aludharsisa Clootsa na tle jego utopii spotecznej, „Euhemer” 1967 ur 4-5, s. 47-57.
} 
„mówca rodzaju ludzkiego”, Cloots oficjalnie występował u jakobinów i w Konwencji Narodowej na rzecz przeksztalcenia Francji w republikę sankiulotów, która podjęłaby zbrojną ekspansję tej rewolucji w Europie w imię solidarności wszystkich plebejuszy w walce $z$ międzynarodowym despotyzmem królów i arystokratów. Robespierre uznał te poglądy Clootsa za kontrowersyjne i doprowadzil do zgilotynowania Clootsa wraz z bliską mu grupą hebertystów w marcu $1794 \mathrm{r}$.

Ta idea braterstwa ludów i organizacji demokratycznej wspólnoty europejskiej zyskała oddźwięk w literaturze politycznej okresu Insurekcji Kościuszkowskiej. Wówczas to pojawiła się anonimowa broszura w języku polskim i francuskim Uu'agi przyjaciela ludzkości (Réflexions d'un ami de l'humanité) wzywająca opinię publiczną Europy do zwołania pokojowego kongresu wszystkich jej krajów, który uregulowałby w drodze rozmów międzynarodowe konflikty i zapobiegłby podbojom. Broszura zawiera równiėz apel do żolnierzy wszystkich narodów, aby bratali się z Polakami i Francuzami:

Żołnierze wszystkich narodów, powiedzcie tym, co was prowadzą, że odtąd nie chcecie być narzędziami despotyzmu; że jesteście przyjaciółmi ludzkości, i że nie chcecie walczyć, tylko na jej obronę; powiedzcie im, że Francuzi i Polacy są to wasi bracia, że nie chcecie we krwi ich broczyć. Ludu Europy, podnieś twój glos a nie twoje ręce; teraz potrzebna jest insurekcja braterstwa i ludzkości, nie zaś insurekcja zajadłości, pożogów i mordów 12 .

Podczas Insurekcji wydano również przekład Ruin Volneya, a wlaściwie ich pierwszą, polityczną część, zawierającą idę̧ republiki powszechnej i solidarności ludów uciskanych przez despotyzm monarchów europejskich ${ }^{13}$.

Kontynuatorem republikańskiej idei braterstwa ludów był w okresie Dyrektoriatu członek Sprzysiężenia Równych Babeufa i autor Manifestu Róu'nych Pierre-Sylvain Maréchal, najgorętszy i najbardziej konsekwentny orędownik sprawy polskiej w ostatnim ćwierćwieczı XVIII wiekı. To jego polonofılstwo dało o sobie znać właśnie w jednej z picrwszych antynapoleońskich broszur we Francji, a zarazem w pierwszej broszurze tego typu opublikowanej w języku polskim, która stanowi przedmiot naszej uwagi. Chodzi o jego anonimowy pamflet Correctif à la gloire de Bonaparte ou Lettre à ce général, opublikowany w listopadzie 1797 roku przez paryskiego wydawcę Lenfanta, który wydał jednocześnie jego przekład włoski. Anonimowy przekład polski ukazał się

\footnotetext{
12 L'u'ugi przyjaciela ludzkości, b. m. i d. wyd., s. 6. Por. B. Leśnodorski, Polscy' jakobini. Karta z dzicjóu' insurekcii 1794 roku, Warszawa 1960), s. 279-285.

1.3 Por. M. Skrzypek, Iolne'y dums les Lumières polonwises, w: Iolne'y et les idéologues, ed. J. Roussel, Angers 1988. s. 357-368. 
na przełomie 1799 i 1800 roku jako Promemoria Bounaparcie't |zachowujemy dokładnie tytul oryginału - M. S.].

Rzadki jego egzemplarz (jeden z czterech zarejestrowanych w katalogu centralnym starodruków Biblioteki Narodowej) zachował się w Bibliotece Uniwersytetu Warszawskiego pod sygnaturą 14335(). Pochodzi on ze zbiorów Kajetana Kwiatkowskiego (1764-1823), związanego z Kollątajem publicysty i uczestnika Insurekcji Kościuszkowskiej. Z Kołłątajem łączyła go myśl, że wyzwolenie Polski winno dokonać się przez włączenie do ruchu niepodległościowego mieszczan i chłopów.

Kwiatkowski własnoręcznie umieścil na dole strony tytułowej Promemoria Boumaparcie datę wydania: „R-11 180()” jako datę powstania oryginału, a że był to oryginal francuski, mógł polski czytelnik dowiedzieć się na podstawie jego rękopiśmicnnego przekładu, którego kopia zachowala się w zbiorach Ossolineum we Lwowie: List do generata Buonaparty ${ }^{15}$. Broszura Promemoria Bommaparcic zawiera dorzucony przez polskiego wydawcę krótki wstęp, który sugeruje, że Napoleon przeczytał ten utwór po powrocie z Egiptu do Francji i że ten utwór zrobił na nim głębokie wrażenie. Skoro wiemy, że Napoleon powrócił z Egiptu 9 października 1799 roku, to nie ulega wątpliwości, że polski tekst broszury mógł ukazać się na przełomie 1799 i 1800 roku. Możemy więc przyjąć datę podaną przez Kwiatkowskiego, zwłaszcza, że przemawia za nią informacja dotycząca Promemoria Bomnaparcie, którą znajdujemy w rękopiśmiennym katalogu książek wydanych w Polsce w latach 1792-1800. Autor informacji podaje dokładny opis bibliograficzny broszury i dorzuca uwagę: "Czytałem ją 16 jant. 1800. Kosztuje 3 zł”|r. Musiała też ona zdobyć sobie popularność w okresic Księstwa Warszawskiego, skoro Karol Surowiecki jeszcze w 1814 roku tępił jej antyklerykalne tyrady ${ }^{17}$. Wyrazona w tej broszurze antynapoleońska postawa reprezcntuje wczesny etap „czarnej legendy” generała, wyrażający rozczarowanie republikanów do jego polityki zagranicznej, a zarazem nadzieję, że uda się go jeszcze wykorzystać w realizacji demokratycznej idei braterstwa ludów. Promemoria Bonnaparcie wyraża solidarność z walczącymi Polakami i stanowi pod tym względem kontynuację konsekwentnej polonofilskiej postawy Maréchala, coraz wyraźniej akcentowanej od pierwszego rozbioru Polski. Wprawdzie wewnętrzny upadek Polski wiąże się u Maréchala z égoizmem szlachty jako stanu uzurpującego sobie

It [P. S. Maréchal], Correctif ì la gloire de Bonapurte ou Lettre à ce gécuéral, A Venise et se trouve à Paris chez

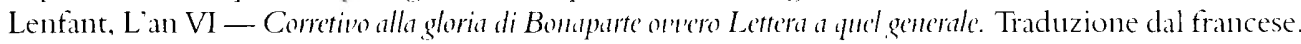
A Venezia e si trova a Parigi, presso Lenfant. Anno VI - 1797. Promomoria (sic) Boumaparcic (sic) dla

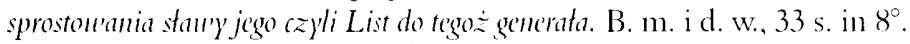

15 List do gencrata Buomapart), frimaire roku VI, dawnego stylu w listopadzie roku 1797, Biblioteka Ukraińskiej Akademii Nauk we Lwowie, rękopis 960.

16 Spis ksiażek z gazat ufozonly 1792-1800. Rękopis Biblioteki Muzeum Czartoryskich w Krakowie, sygn. 3284 II, k. 30. Notatka pochodzi z „Gazety Korespondenta Warszawskiego”, 12 IV 1800.

17 Por. K. Surowiecki, Cudou'ny' schytck osicmmastego u'ick'n, Warszawa 1814, s. IX-XI. 
prawo reprezentowania narodu, ale ostrze krytyki kierowane jest pod adresem państw ościennych i ich dworów, a w szczególności Katarzyny II, która wymusiła na sejmie rozbiorowym „podjęcie decyzji prowadzących do całkowitej ruiny pięknego i nieszczęśliwego kraju”' ${ }^{\prime \prime}$. Maréchal obciąża winą również pozostałe państwa europejskie, których bierność umożliwila prowadzenie polityki aneksji, a ta - jak powiada — „nie napotkała na opór ze strony innych ludów, tchórzliwych świadków jej rozbioru"1".

Perspektywę odrodzenia Polski upatruje Maréchal w solidarności wszystkich ludów, które będą uważaly pojęcia ojczyzny i ludzkości za komplementarne wobec siebie, gdyz

te dwa słowa wyrażają tę samą ideę rozważaną z dwóch różnych punktów widzenia. Ziemia rozważana jako wspólna matka wszystkich ludzi spojrzy na wszystkie swoje dzieci jak na zaprzyjaźnionych bracien".

Maréchal sądzil, że te idee wprowadza w życie Rewolucja Francuska, i dlatego wiązał losy uciskanych ludów z jej powodzeniem i z dokonaniem w Europie przeobrażeń opartych na jej zasadach. W sztuce Le jugement dernier des rois, która pojawiła się w szczytowym momencie radykalnego etapu Rewolucji, w 1793 roku, Maréchal snuje wizję zbratanych zwycięskich sankiulotów Europy, przybyłych do Paryża na sejm, który miał osądzić despotów. Sankiulota polski brata się tam z sankiulotami francuskimi, rosyjskimi, austriackimi i pruskimi.

Wybuch Insurekcji Kościuszkowskiej potraktował Maréchal jako początek realizacji swojej utopijnej wizji demokratycznego społeczeństwa światowego.

Jeżeli Polska kierująca się naszym przykładem — pisał w 1794 roku — zdola się wyzwolić, jak wszystko na to wskazuje, za nią ruszy Rosja i Porta Ottomańska. Wolność tak długo pogrzebana pod ruinami Grecji $[\ldots]$ z wież minaretów zaprosi Azję i Afrykę do zbratania się z niepodległą Europą²1.

Nie znamy źródeł informacji Maréchala o sytuacji insurekcyjnej w Polsce. Pisał o niej, kierując się raczej szlachetnymi intencjami niż znajomością konkretnych polskich warunków. Trudno przecież wyobrazić sobie polskich chłopów pańszczyźnianych w roli rewolucyjnych sankiulotów francuskich. Trudno też wyobrazić sobie żywiołowy odruch zemsty, jakim były wypadki z 9 maja i 28 czerwca 1794 roku w Warszawie, jako świadomy rewolucyjny akt zmierzający do obalenia w Polsce królestwa, a tak przecież należy rozumieć słowa Maréchala:

\footnotetext{
15 P. S. Maréchal, Histoire de la Russie, Paris 1807 [I wydanie 1802], s. 346.

Ibide'm, s. 353.

21) Idem, Le jugement dernier des fors, Paris l'an II (1793), s. 11.

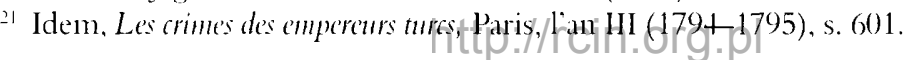


Nie ulega wątpliwości, że to nasz przykład fermentuje juz w sercach uciskanych Polaków i każe in uciec się w tej chwili do powstania: Warszawa ujrzała już swój dzicń 14 lipca na wzór Paryża. Tchórz i zdrajca Stanisław August, który zaprzedał swój kraj Katarzynie, nie wie, gdzie się podziać. Święta Rewolucjo Francuska, tak, ty obiegniesz świat!?-2

Mimo klęski Insurekcji Kościuszkowskiej Maréchal nie przestawał interesować się problemem odrodzenia Polski, które zaczął wiązać z postacią Napoleona. Jednak jego stosunek do Bonapartego był od początku ambiwalentny. Był przecież Maréchal członkiem Sprzysięzenia Równych i należał do ścisłego jego kierownictwa. Główną rolę w rozbiciu tego ruchu odegrało wojsko pod rozkazami Napoleona. Generał ten realizował równiezz zagraniczną politykę Dyrektoriatu, a w latach 1796-1797 kierował kampanią włoską, w której wzięły udział legiony polskie. Babuwiści widzieli w nim przyszlego dyktatora, który realizował obce im cele w polityce miçdzynarodowej. Zasady tej polityki wyłożył później Philippe Buonarroti, jeden z przywódców sprzysiężenia, który prawdopodobnie przetłumaczył broszurę Maréchala Correctif à la gloire de Bonaparte i podjął się jej rozpowszechnienia we Włoszech ${ }^{23}$. Buonarroti przypomnial te zasady w klasycznej dziś książce z 1828 roku:

Miłość dla republiki sprzysiężeni łączyli z miłością dla ludzkości, której szczęście było $\mathrm{w}$ istocie ostatecznym celem wszystkich ich projektów. Gdyby życzenia ich zostały spełnione, nic nie stałoby na przeszkodzie, żeby ten sam duch równości i sprawiedliwości, który miał zapanować między obywatelami, kierował postępowaniem republiki wobec cudzoziemców i sprzysiężeni pragnęli, żeby lud francuski uważając sic̨ za czlonka wielkiego społeczeństwa ludzkiego przyczyniał się swą mądrością i przykładem do zapewnienia powszechnego pokoju i wzbudzenia w rządzie poszanowania dla praw, które natura przyznała wszystkim ludziom²+.

Już w samych początkach kariery wojskowej Napoleona Babeuf dopatrywał się w swoim czasopiśmie .,Trybun Ludı” z 30 marca 1796 roku oznak dyktatury, której celem byłoby wygaszenie rozbudzonych aspiracji egalitarnych ludu. W dwa miesiące później został aresztowany i po rocznym procesie w Vendôme stracony. W tym czasie Napoleon odnosił militarne sukcesy w kampanii włoskiej połączone z korzystnymi dla Francji traktatami zawartymi z Austrią w Leoben i Campoformio, z Państwem Kościelnym w Tolentino i z przedstawicielami państw niemieckich zebranymi w Rastadt.

22 Idem, Tableanx historiques des ćléne'ments réblutionnaires, Paris an III, (1794-1795), s. 143.

${ }_{23}$ Jedyny egzemplarz włoskiego przekladu Corrtito alla gloria di Bomaparte (zob. przypis 12), zacluowat się w Biblioteca Nazionale Centrale we Florencji, sygnatura: Collec. Palat. Misc. 3.1).8.t.

${ }^{2+}$ Ph. Buonarroti, Sprzjsięzenic Rón'nych, th. A. Jeżewski, t. 1. Warszawa 1952, s. 225. 
Te traktaty i te rozmowy dyplomatyczne wskazywały, że Napoleon nie zmierza do realizacji pięknej, ale utopijnej idei demokratów, jaką było unicestwienie despotyzmu w Europie i wyzwolenie uciskanych ludów, ale kieruje się własnymi interesami bardziej przyziemnymi, czy też konkretnymi interesami strategicznymi Francji. Chodziło o otoczenie jej kordonem zależnych od niej republik.

Napoleon oficjalnie realizował tę politykę Dyrektoriatı, zakładając na zajmowanych ziemiach włoskich Republikę Transpadańską, Republikę Cyzpadańską, Republikę Lombardzką, a następnie tworząc z dwóch ostatnich Republikę Cyzalpińską. Proces ten trwał nadal jeszcze po ukazaniu się broszury Maréchala. W latach 1798-1799 powstała Republika Rzymska, następnie Republika Szwajcarska i Republika Batawska (na obszarze I Iolandii), zaś rok później Republika Partenopejska (na obszarze Królestwa Neapolu).

W takiej to skomplikowanej wewnętrznej i zewnętrznej sytuacji politycznej, pelnej sprzecznych tendencji i niespodziewanych zwrotów, powstała broszura Maréchala. $\mathrm{Na}$ ostateczny jej kształt wplynęly dokonujące się przemiany w świadomości autora. W jego pismach z tego okresu pojawia się nuta zwątpienia co do możliwości wprowadzenia ustroju republikańskiego i demokratycznego dzięki inicjatywie oddolnej mas plebejskich. Aresztowanie i proces babuwistów, który odbył się przy nikłym proteście ulicy latwo opanowanym przez Dyrektoriat, podważył jego wiarę w lud jako podmiot historii. Jego miejsce zajmuje wybitna jednostka, która miała realizować plebejskie aspiracje, wznosząc się ponad mentalność ludu. Miała być uosobieniem Roussowskiego ideału ustawodawcy, który byłby istotą niemal boską. Potrafilby się on wznieść ponad emocje i doraźne interesy ludu i realizować cele odległe, których lud nie potrafi przewidzieće 25 .

Nadzieja na urzeczywistnienie królestwa wolności, równości i sprawiedliwości przybiera w ostatnim obszernym dziele filozoficznym Maréchala Podróże Pitagorasa postać nicmal mesjanistyczną. Oto jak ich autor kreśli wizerunek przyszłego zbawcy ludzkości:

Na jego głos kajdany spadają z rąk nieszczęśników, którzy czekali daremnie na wysłuchanie. Spada maska z oblicza hipokryzji. Ludy zbliżają się do siebie, rzucają się sobie w objęcia, zdziwione, że tak długo nie mogły sobie przypomnieć o braterstwie, i zawstydzone, że potrzebowaly kogoś, kto by im o tym powiedzial. Tylko jeden czlowiek o dobrych intencjach 
dokona tego cudu, pierwszego cudu na ziemi. Tylko jeden czlowiek z uczciwymi zamiarami zmieni oblicze świata i sprowadzi na ziemię szczęśliwy wiek Astrei ${ }^{2 n}$.

Błyskotliwa kariera Napoleona powodowala, że Maréchal gotów był w nim widzieć opatrznościowe narzędzie budowy światowej republiki ze stolicą w Paryżu i zainaugurowania wieku braterstwa ludów. W miarę jak Bonaparte zawodził pokładane w nim nadzieje, podziwowi towarzyszy rozczarowanie, wyrażone w skierowanej do niego w formie listu broszurze. Stąd apostrofa:

Nie, Bounaparte. Jeszcze ty nie jesteś wielkim człowiekiem, nie jesteś jeszcze bohaterem. Masz geniusz, masz talenta wojskowe, jesteś szczęśliwy i przy tym jesteś najpierwszym generałem zostającym pod rozkazami... Ale nie dokończę $e^{27}$.

Chodzi oczywiście o cesarza Austrii, niemieckich książąt i papieża. Tymczasem według Maréchala geniusz Napoleona połączony z potęgą republikańskiej armii francuskiej mógłby dokonać dzieła wyzwolenia wszystkich narodów Europy spod panowania despotów. Gdyby Napoleon poparł plebejskie rozruchy w Rzymie, to „w proch by obrócił starożytną teokrację, jeden z najgorszych despotyzmów". Tymczasem zadowala się okupem i „listownie caluje z uniesieniem sandały zgrzybiałego wieszczka”" ${ }^{2 x}$, czyli Piusa VI.

Przypisy dorzucone do polskiego wariantu Correctif à la gloire de Bonaparte, czyli do Promemoria Bounaparcie, rozwijają ten wątek poglębiając antyklerykalną wymowç dziela: Tak na przykład zdanie: „Ti révolutionne d'abord l'Italie, puis tu lui prêches la prudence et le calme" rozbudowane zostało w sposób następujący:

Najprzód rewolucjonizujesz Włochy, wywracasz po części despotyzm, fanatyzm, bezprawne przywileje, a potem zalecasz spokojność, roztropność, i każesz czcić ołtarze wspomnianych wrogów, z których wylęgły się wszystkie rodzaju ludzkiego nieszczęścia ${ }^{20}$.

Polski thumacz nie ogranicza się zresztą do tego rodzaju rozwijania myśli francuskiego autora, bo dodaje własne obszerne przypisy w rodzaju:

Ze wszystkich zawartych pokojów najwięcej zadziwia pokój ze Stolicą Apostolską. Bounaparte stojąc z wojskiem francuskim w Foligno,

\footnotetext{
2t. P. S. Maréchal, Toyuges de Pythagore, t. 1, Paris, l'an VII (1798-1799), s. 39.

${ }_{27}$ Promemoria Boumaparcie, s. 12.

$2 *$ Ibidem, s. 7.

${ }^{27}$ Correctif a la gloire de Bomaparte ou lettre à a général. Cyt. wg przedruku w "Revue historique de la Révolution Française" 1912, 11r 9, s. 311: Promemoria Bommaparcie, s. 21.
} 
po odbyciu tylko pięciu marszów do Rzymu, byłby panowanie papieskie zniszczył. Już władzy duchownej piastunowie myśleli o nie jej utrzymaniu, ale o ratowaniu swych własnych majątków, o schowaniu podejrzanych bogactw. Już żywsza część ludu śpiewała na ulicach: „Addio Santissimo padre, addio santissimo nipote", część umiejąca stan teraźniejszy z dawnym porównywać, wyglądała bohatera francuskiego, reszta zaś wiedząc, że i siły cudów strętwiały, ze skruszonym sercem oddała się losowi. Wtcm nagle rozchodzi się wiadomość o zawartym pokoju, w którym Bounaparte podług zdania republikanów, wszystkie swe obwieszczone plany, polityczny interes swego narodı, swą władzę założyciela włoskiej wolności, tudzież sprawę rozumı i rodzaju ludzkiego za 25 milionów liwrów sprzedał ${ }^{31}$.

Maréchal wytyka Napoleonowi analogiczną postawę wobec Austrii. Oto, będąc już w pobliżu Wiednia, zawiesza działania wojenne i pertraktuje z dworem cesarskim. Tymczasem powinien był

jedną nogą stanąć na Rzymie, drugą w Wiedniu, lewą ręką zatopić okrutny rząd angielski, a prawą wskrzesić rozszarpaną Polskę ${ }^{3 !}$.

Polski thumacz opuścił przy wyrazie „Polska” przymiotnik „zniewoloną”, uznając, że dopóki Polacy walczą w legionach, duchowo pozostają wolni.

Maréchal zarzuca następnie Napoleonowi, że nie starał się pozyskać do wspólnej walki Kościuszki, który po opuszczeniu więzienia w Petersburgu wyruszył pod koniec grudnia 1796 roku w podróż do Stanów Zjednoczonych, skąd po otrzymaniu zaproszenia od Dyrektoriatu przybył do Francji i nawiązał ścisłe kontakty z republikanami, które utrzymywał jeszcze po 1801 roku, spotykając się z nimi w swojej posiadłości w Berville kolo Fontainebleau. W ich otoczeniu umacniala się jego pełna rezerwy postawa wobec Napoleona. Po zamachu stanu 18 brumaire’a (9 listopada 1799) Kościuszko „stal się zdecydowanym przeciwnikiem Pierwszego Konsula"32. Oczywiście stosunki między Kościuszką a Napoleonem nie układały się na zasadzie osobistej antypatii, a podłoże ich wzajemnej niechęci było głębsze, jako że Kościuszko zgodnie ze swym republikanizmem i demokratyzmem liczył na wybicie się Polaków na niepodległość własnymi silami całego narodu. Ostrożnemu jego angażowaniu się w sprawę legionów towarzyszyło przekonanie o niepotrzebnych stratach polskiego żołnierza na polach walk nader od Polski odległych, jak chociażby San Domingo.

is Promemoria Bonnaparie', s. 26.

3 Correctif, s. 127; Promemoria. s. 9.

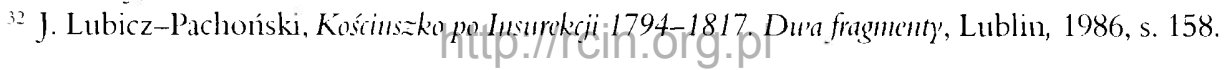


Niechętny stosunek Napoleona do Kościuszki znany był autorowi Correctif, a dzięki broszurze Promemoria Bounaparcie dowiedzieli się o nim liczni jej polscy czytelnicy. Maréchal zwraca się mianowicic do generała Bonaparte z pytaniami o charakterze retorycznym:

Nie poznałeś się na umyśle Kościuszki. Po cóż on puszcza się na morza? Czemu nie zachowujesz go dla Polski? Z jakiej przyczyny, wojny i nieszczęść jego towarzysze przez ciebie opuszczeni zostali w twojej dyplomacji, kiedy ich po przyjacielskı w twoim przyjąłeś obozie? Jeszcze raz chcesz się osłonić płaszczem głębokiej polityki. A ja ci zawsze powtórzę imieniem wszystkich przyjaciól Prawdy i Rozumu, że nic nie znaczy dyplomacyjna polityka obok sprawiedliwości, geniuszu i zwycięstwa ${ }^{33}$.

Ta krytyka Napoleona przez autora Correctif à la gloire de Bonaparte oparta byla wyłącznie na jego ambiwalentnej postawie wobec legionów w okresie pertraktacji dyplomatycznych, które przyniosły zagranicznej polityce Dyrektoriatı widoczne sukcesy. Autor Correctif, wychodząc od abstrakcyjnej zasady wcielania w życie ideału powszechnej republiki, braterstwa ludów i ich solidarności w walce z despotyzmem, mógl znać jedynie stanowisko Kościuszki wyłożone w Memoriale przedłożonym w 1793 roku ministrowi Lebrunowi. Wówczas Kościuszko był przekonany, że „Rzeczpospolita francuska usiłuje rozszerzyć w całej Europie zasady wolności i równości”. Sądzil, że Francja pomoże zrealizować te idee w Polsce, a Polska byłaby predestynowana, ze względu na podobieństwa języka i obyczajów, do „szybkiego rozszerzenia republikanizmu w Rosji, do zasadzenia drzew wolności nawet wśród lodów Petersburga" "3t. Akceptował też Kościuszko ideę kordonu republik, który otaczałby Republikę Francuską i pozwoliłby realizować jej dziejową misję wyzwolenia narodów.

Maréchal nie mógł jednak znać dzieła Kościuszki i Józefa Pawlikowskiego: Czy Polacy u'ybić się mogq na niepodleģość, które ukazało się w 180() roku w Paryżu; a więc po opublikowaniu przez Maréchala Correctif. W utworze tym Kościuszko bardziej liczył na przykład republikanów amerykańskich, z którymi utrzymywał stałe kontakty, niz na francuski Dyrektoriat, bardziej na ogólnonarodowy ruch partyzancki na wzór Czarnieckiego niż na pomoc z zewnątrz. Jeśli naród zmierza do niepodległości nie przez „własne usiłowanie”, ale poprzez „obce wsparcie lub łaskę” — twierdził tam Kościuszko - to nigdy nie dojdzie ani do „szczęścia ani cnoty, ani sławy”. Pisać takie słowa i je publikować w 1800 roku pod bokiem Napoleona w Paryżu, oznaczało nawiązywać bezwiednie do republikańskiej myśli Maréchala, który proponował generałowi Bonapartemu, aby zaprowadził Kościuszkę pod bramy Warszawy.

\footnotetext{
33 Promemoria Bommaparcie, s. 11.

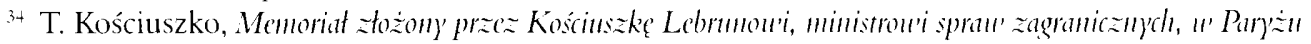
1793 rokn, w: Pisma Tademsa Kościnszki, wyb. objaśn. i wst. I1. Mościcki, Warszawa 1947, s. 71.
} 
Maréchalowska krytyka Napoleona nie jest krytyką polonofila skierowaną przeciw wrogowi Polski, ale stanowi wyraz rozczarowania, że genialny człowiek nie wykorzystał swoich talentów wojskowych dla realizacji ogólnoświatowego dzieła wyzwolenia ludów. I z takiej perspektywy należy je ocenić. To humanistyczne stanowisko zaangażowane w niepodległość uciskanych narodów cenne jest i interesujące ze względu na pasję demokraty, orędownika cierpiącej ludzkości. Pasję tę oddaje zwłaszcza centralny fragment Promemoria Bonnaparcie:

Jako! Bounaparte mógł był nadać niepodległość ludom nad Tybrem, Dunajem i Wisłą osiadłym, Bounaparte był orłem (Generale! Wszak nim zwać się lubisz i sam o tym powszechność uprzedziłeś), orłem, który jednym oka rzutem mógl rozproszyć królików Europy, a on dozwala polityce austriackiej, iż go w swym locie wstrzymuje, zniża się do ugód z wiarolomnymi dworami, zdradza (nie jest to za mocny wyraz), zdradza sprawę wiclkiego narodu, u którego zupełne ma zaufanie: zdradza prawa narodów włoskich dla przypodobania się mniemanemu rzymskiemu królowi i potwierdza spokojnym wzrokiem podział nieszczęśliwej Polski. Pod swoją komendą ma sto tysięcy Francuzów jeszcze zwyciężać chciwych, a nie przychodzi mu na myśl ująć się za słaby naród, któremu ojczyznę wydarto. Zbrodni najszkaradniejszej nadaje sankcję swym występnym milczeniem i puszcza w niepanięć najwyżej oburzający postępek, jakiego jeszcze nigdy popełnić nie śmiano. Patrioci polscy, Irlandczykowie, Szkotowie, Anglicy, patrioci od Renu, następcy dawnych Greków, wszystkie narody wlepily w niego swe pragnące wzroki; nie pozostaje mu nic więcej, jak wydać haslo, a cała Europa na widok jego trójkolorowej kokardy w masie powstaje ${ }^{35}$.

Jeśli porównamy polski przekład z francuskim oryginalem Correctif, to zauważymy drobne, ale latwo dające się wytłumaczyć zmiany. Otóż Promemoria Bomnaparcie przystosowano do potrzeb polskiego czytelnika, opatrując tę broszurkę wstępem. Dowiadujemy się z niego, że

ten list po francusku napisany dostal mu się w ręce i zrobil na nim tak wielkie wrażenie, że przytomni w owym miejscu przez długi czas pomieszanie i walkę uczuciów na jego twarzy widzieli. Przeraził się on zapewne swymi wielkimi błędami otwarcie mu w tym małym piśmie wystawionymi, a z których złe skutki niedawno przepędziły go z Egiptu do Francji ${ }^{36}$.

35 Correctif, s. 128; Promemoria, s. 12-13.

36. Promemoria, s. 3. 
Te błędy, które polski tłumacz wytyka Napoleonowi - i co jest istotne - francuskiemu Dyrektoriatowi, wynikają stąd, że Bonaparte zapomniał o głównym celı, jakim winna być rzeczpospolita powszechna realizująca prawa człowieka. W przekonaniu tłumacza lub wydawcy Promemoria, który musiał być republikaninem równie konsekwentnym jak Maréchal, ,jak woda z ogniem, tak despotyzm z republikanizmem nigdy zgodzić się nie mogą" ${ }^{37}$. Dlatego wszelkie układy pokojowe z dworami monarchów są zbędne, i stanowią zdradę zasad i misji Republiki Francuskicj, jaką jest republikanizacja świata, a w konsekwencji era wiecznego pokoju. Rozumowanie to, idące tropem Maréchala, jest w gruncie rzeczy ahistoryczne. Zaklada ono kres historii i niezmienne trwanie powszechnego braterstwa ludzkiego ufundowanego na zasadach „rozumu i sprawiedliwości". Jedyną istotną zmianą podyktowaną patriotyczną świadomością polskiego tłumacza jest pominięcie w zdaniu: "Transporte à Paris le congrès de Rastadt et sois y fondateur d'une république wniterselle” koncowej jego sekwencji: „dont la France serait le chef-lien et principal boulevard" 3x. Zamiast tej sekwencji pojawia się zwrot zachęcający Napoleona do ufundowania republiki „powszechnej i sprzymierzonej”, a więc republiki bez państwa występującego w roli hegemona.

W odróżnieniu od francuskiego oryginału, broszura Promemoria Boumaparcie zawiera jednak pewne elementy czarnej legendy. Przejawia siç to już w samym tytule utworu, gdzie przekręcone zostało nazwisko Bonaparte na Botnaparte zamiast Buonaparte, które miało podkreślać niefrancuskie, bo z włoska brzmiące nazwisko Napoleona. Celowała w tym zwłaszcza czarna legenda Napoleona w Anglii. W 1809 roku pojawila się tam broszura Napoleon Buonaparte ummasked, ale jeszcze w 1814 roku Chateaubriand wydal na fali wczesnego romantycznego i legitymistycznego antybonapartyzmu $D e$ Buonaparte et des Bourbons. Typowy dla późniejszej czarnej legendy jest tu więc wątek karykatury, satyry, jak również anegdotycznej plotki, który pojawia się też w przypisach polskiego tlumacza. Znajdujemy tam między innymi informację, że matka Napoleona miała za kochanka generała Marboeufa, który w 1768 roku zawojował Korsykę. Z tego związku miał jakoby urodzić się w 1769 roku Napoleon.

Jednak te szczegóły nie zmieniają podstawowych założeń krytyki Napoleona przeprowadzonej z pozycji republikańskich. Jej punktem wyjścia nie jest wrogość i antypatia zmierzająca do ośmieszenia i moralnego unicestwienia przeciwnika, ale rozczarowanie, któremu towarzyszy nadzieja, że uda siç pozyskać genialnego dowódcę, wybitnego męża stanu dla sprawy demokracji i wolności ludów. Broszura Marćchala mieści się pod tym względem w rzędzie republikańskich utworów publicystycznych, które nie sytuowały Napoleona po drugiej stronie barykady, ale jedynie ostrzegały przed wojskowymi rządami, jak to było w przypadku broszury Barbeta i Darceta: L'agonic de la

37 Ibidem, s. 4.

35 Ibidem, s. 23. 
liberté ou gare le gounernement militaire (1798) czy też napisanego w formie listu pamfletu: Dubreuil à Bonaparte skierowanego przez republikanina Dubreuila do Napoleona jako przyszłego despoty, jeśli nie zmieni swej polityki.

W Polsce broszura Promemoria Bonnaparcie sytuuje się w demokratycznej tradycji sięgającej korzeniami do anonimowej publicystyki okresu Insurekcji kościuszkowskiej oraz Towarzystwa Republikanów Polskich powstałego w 1798 roku, jak również do emigracyjnej paryskiej Deputacji Polskiej (Gabriel Taszycki, Franciszek Ksawery Dmochowski), z którymi Kościuszko był ideowo i osobiście związany. W tych też środowiskach republikańskich należałoby szukać inspiracji wydania Promemoria Bounaparcie. Elementy tej republikańskiej i demokratycznej tradycji pojawią się w tym czasie w epigońskiej poezji oświeceniowej z przełomu XVIII i XIX wieku (Józef Sygiert, Antoni Pełka). Ci młodzi poeci, których twórczość pozostaje po większej części w rękopisach, byli związani ze środowiskiem Akademii Krakowskiej. Utrzymywali oni kontakt z Franciszkiem Wężykiem, autorem Ody' na pou'rót polskicgo u'ojska 18 grudnia 1809. W tym samym czasie, kiedy ukazała się broszura Promemoria Boumaparcie, Kajetan Koźmian pisał Odę na wojnę roku 1800 ukończona batalia pod Marengo, ale skończył na Odzie na upadek dumnnego, w roku 1815 zwracając swe sympatie ku Aleksandrowi I. Inny poeta z okresu przełomu między klasycyzmem i romantyzmem, uczestnik kampanii 18121814 roku Kazimierz Brodziński, daleki był od wiązania idei niepodległościowych z politycznym radykalizmem, zanim „ukorzył się przed geniuszem narodu” w 1830 roku. Przeżywał natomiast rozterki co do słuszności obranej drogi do niepodległości u boku Napoleona (Zotnierz nad rzeka Mosku'a " roku 1812). Dalej posunie się w swych rozterkach Kantorbery Tymowski, który, przedstawiając się jako uczestnik walk w Hiszpanii i świadek scen uwiecznionych przez Goyę między innymi w obrazie El tres de mayo (3 maja 1808 - Rozstrzelanie pou'stancóu' madryckich), snuł Dumania żotnierza polskicgo "starożytny'm zamku Mauróu' nad Tagiem (1810). Jakże bliskie są te „dumania” protestom zrepublikanizowanych legionistów, uczestników kolonialnych wojen na San Domingo, które byly przedmiotem troski polskich republikanów, zwłaszcza Kościusz$\mathrm{ki}^{3 \prime \prime}$, przyjmującego powracających z Antyli legionistów w Berville po 1802 roku.

Polączenie się prądów liberalnych, demokratycznych z romantyzmem krzewiącym idee wolnościowe nastąpiło jako reakcja na rządy Świętego Przymierza i zwiastowało dążenia przygotowujące Wiosnę Ludów. Pisarze romantyczni we Francji: Victor Hugo, autor Ody' na kolummę na Placu Vendôme (1827), z której Restauracja już w pierwszych dniach rządów zwaliła posąg Napoleona, pisarz, który później w Nędznikach wyrażał nostalgię za demokratycznymi i humanitarnymi idealami 1793-1794 roku; Alfred de Vigny, który w odsunięciu od włazy Burbonów widział możność odrodzenia francuskiego patriotyzmu doby rewolucyjnej; Pierre-Jean de Béranger, liberalny i antyklery- 
kalny poeta i autor popularnych piosenek sławiących Rewolucję Francuską i Napoleona — wszyscy oni (nie wylączając Balzaca i Stendhala) wyrugowali czarną legendę Cesarza i uczynili zeń spadkobiercę ideałów 1789 roku oraz wyzwoliciela ludów spod władzy feudalnych despotów. Do odrodzenia się kultu Napoleona w latach 1830-1840, kiedy to prochy cesarza zmarłego w 1821 roku na wyspie Świętej Heleny zostały sprowadzone do Paryża (1840) i złożone w mauzoleum (dawniej kościól) Inwalidów, przyczyniło się poczucie jego „męczeństwa” za sprawę narodową. Stał się on w tym czasie uosobieniem narodowego patriotyzmu w walce z monarchiczną Europą, która chciała zniweczyć osiągnięcia Rewolucji Francuskiej.

To zjawisko nie ograniczało się do Francji — jak zauważa historyk „czarnej legendy" Cesarza. - Ruchy narodowe, które władcy podsycali, by wzniecić nienawiść przeciwko dominacji Napoleona, obrócily się przeciw monarchom Świętego przymierza, którzy sądzili, że w Wiedniu ustanowią mapę Europy na wiele stuleci. Niemcy, Wlosi, Polacy czy Belgowie powstaną z okrzykiem: „Niech żyje Napoleon”!"”

W dobie polskiego romantyzmı człowiekiem, który nawiązał do demokratycznych i ideałów Rewolucji Francuskiej, a zwłaszcza do koncepcji republiki powszechnej zbratanych ludów wyzwolonych spod jarzma europejskich despotów, był Adam Mickiewicz, który widział w Napoleonie prototyp duchowego przywódcy całej cierpiącej ludzkości, a szczególnie Polaków, którzy utracili narodowy byt, ale nic utracili ducha wolności. W artykule O dą̇eniu lıdóu' Europy' ogloszonym w „Pielgrzymie Polskim” Mickiewicz pisze, że

już za rewolucji francuskiej odżyła w sercach pamięć braterstwa narodów rozerwanego przez rządy. W wojnach Napoleona ciemne przeczucie jedności europejskiej tłumaczyło się łączeniem się partii popularnych z Francuzami ${ }^{+1}$.

Ruchy narodowe, które pojawiły się w okresie Świętego przymierza doprowadzając do powstań 1830) roku i Wiosny Ludów są dla Mickiewicza kontynuacją republikańskiej świadomości przełomu XVIII i XIX wieku, tylko że świadomości tej patronuje romantyczny duch Byrona stanowiący „wytwór Napoleona”. Dla Mickiewicza jest sprawą oczywistą, że „promień, który rozniecil ogień poety angielskiego, wyszedł z ducha Napoleona"+2, który reprezentował nie tylko siłę militarną, ale duchową, bo porwał za sobą ludzi do wielkich czynów, obudził w nich ducha wolności, który patronuje na-

\footnotetext{
*" J. Tulard, L'Anti-Napoléon. La légende noire de l'Empereur, Paris 1965, s. 221.

${ }^{+1}$ A. Mickiewicz, Dzicła, t. 6. Warszawa 1952, s. 111.

+2 Idem, Literatura stou'iańska, w: Dzieta, t. 12, Warszawa 1955, s. 216.
} 
rodowym ruchom Europy. Napoleon minął, ale idea z nim związana pozostała. Służył przecież „duchowi bezinteresownej propagandy”, duchowi ekspansji nie Francuzów, ale ich zasad.

Był, może bezwiednie, zbrojnym krzewicielem tej rewolucyjnej idei równości: poniżył królów, obalił trony, a wraz z nimi przywileje, nadużycia, niesprawiedliwości, te wszystkie pasożytnicze i zgubne chwasty, które zrodziły się i wzrosły w cieniu tronu królewskiego; ze swych towarzyszy broni, synów ludu jak on, porobil jenerałów, marszałków, książąt armii; jego żołnierze prowadzili układy jak równi z równymi z najwznioślejszymi przedstawicielami starego świata ${ }^{+3}$.

Lansując ideę „narodowego Mesjasza”, Mickiewicz nie sądzi jednak, że będzie nim człowiek pokroju Cromwella, Cezara czy Napoleona, gdyż w historii nic się nie powtarza. Polsce jest potrzebny bohater narodowy, który wyrośnie z polskiego ducha i będzie wcielał w sobie cechy wspótziomków, jak szlachetność, prawość, uczciwość. Taki bohater odpowiadałby raczej postaci Kościuszki i Waszyngtona niz Napoleona:

U nas - pisze Mickiewicz - tak wielkim było i jest imię Kościuszki. Zdaje się, że pierwszym warunkiem przyszłego wielkiego czlowieka musi być szlachetność charakteru, ta serdeczność, ta dobroduszność, która Kościuszce i Washingtonowi zjednala milość wspólczesnych i szacunek potomnych ${ }^{+1}$.

I tak oto powracamy do punktı wyjścia, jaki stanowila ideologia broszury Promemoria Bounaparcie, która została skorygowana przez świadomość romantyczną i wyniesiona na wyższe piętro. Konstruktywna krytyka wskazująca Napoleonowi wartości pozytywne, do których winien był dążyć, przemogła czarną legendę, której elementy pojawiły się w polskiej broszurze z przełomı 1799 i 1800 roku jako coś heterogenicznego, kontrastującego z głównym wątkiem utworu Maréchala.

${ }^{+3}$ Idem, Tip'buna Ludour; Dzicta, loc. cit.

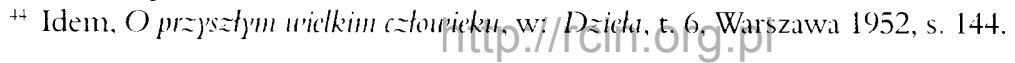

